\title{
Kayıt Dışı İstihdama Neden Olan Faktörlerin DEMATEL Tabanlı Analitik Ağ Süreci Yöntemi ile Değerlendirilmesi
}

Gözde KOCA (https://orcid.org/0000-0001-6847-6812), Department of Business Administration, Bilecik Şeyh Edebali University, Turkey; e-mail: gozde.koca@bilecik.edu.tr

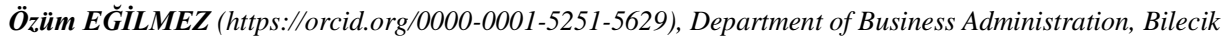
Şeyh Edebali University, Turkey; e-mail: ozum.egilmez@bilecik.edu.tr

Suna GÜLER (https://orcid.org/0000-0002-4365-9740), Department of Business Administration, Bilecik Şeyh Edebali University, Turkey; e-mail: sunaaltintass@gmail.com

\section{Evaluation of the Factors Causing Informal Employment by DEMATEL Based Analytical Network Process Method}

\begin{abstract}
For many years, informal employment is an important problem in Turkey. Especially in recent years, various sanctions and incentives have been applied to prevent/reduce this problem. In this study, MCDM (Multiple Criteria Decision Making) methods are utilized to determine the factors that cause informal employment using expert opinions of five Social Security Supervisors working against informal employment in the Social Security Institution of Turkey. Specifically, DEMATEL (The Decision-Making Experiment and Evaluation Laboratory) is used to determine the relations of the factors with each other, and the Analytical Network Process (ANP) is used to determine the weights associated to the factors. The findings indicate that while "economic factors" prevail to be the foremost essential factors, "unemployment" is determined to be the most critical sub-factor among the macro factors that lead to informal employment.
\end{abstract}

Keywords

Informal Employment, Policy Makers, DEMATEL, ANP, Multiple Criteria Decision Making.

JEL Classification Codes : $\quad$ E26, C60, D80, M19.

\section{$\ddot{\mathbf{O z}}$}

Uzun yıllardır kayıt dışı istihdam Türkiye'nin önemli sorunlarından biridir. Özellikle de son yıllarda bu sorunun önlenmesi / azaltılması için çeşitli yaptırımlar ve teşvikler uygulanmaya başlanmıştır. Bu çalışmada kayıt dışı istihdama neden olan faktörler, ÇKKV (Çok Kriterli Karar Verme) yöntemleri ile Sosyal Güvenlik Kurumu'nda kayıt dışı istihdamla mücadele eden beş sosyal güvenlik denetmeninin uzman görüşüne başvurularak incelenmiştir. Yöntem olarak faktörlerin birbirleri ile olan ilişkilerini belirleyen DEMATEL (The Decision Making Experiment and Evaluation Laboratory) ile bu ilişkileri kullanarak faktörleri ağırlıklandıran Analitik A $\breve{g}$ Süreci (AAS) kullanılmıştır. Kayıt dışı istihdama yol açan makro faktörlerden "ekonomik faktörler" en önemli ana faktör; "işsizlik" en önemli faktör olarak belirlenmiştir.
Anahtar Sözcükler
Kayıt Dışı İstihdam, Politika Yapıcılar, DEMATEL, AAS, Çok
Kriterli Karar Verme. 


\section{Giriş}

Günümüzde sosyal ve ekonomik yapının başlıca sorunlarından birini de istihdam oluşturmaktadır. Ülkelerin gelişmişlik düzeyleri istihdam oranlarına bağlı olarak değişmektedir. Ülkemizde de işsizlik, enflasyonla beraber en çok mücadele ettiğimiz önemli konulardan biridir. Gelişmiş ülkelerin, enflasyonla mücadelede başarı sağlarlarken, işsizlikle ilgili yeterli düzeyde başarı elde edemedikleri görülmektedir ki; Türkiye gibi gelişmekte olan ülkeler de hem işsizlik hem de enflasyonla birlikte mücadele etmek zorunda kalmaktadır. Ayrıca gelişmekte olan ülkeler istihdamın yapısal sorunlarıyla da yüzleşmek durumunda kalmaktadırlar. Özellikle kayıt altındaki işveren ve işçi, yüksek oranda vergi ve prim kesintileriyle karşı karşıya kalırken, kayıt altında olmayan işveren ve işçinin tam tezat olarak bu tür bir durum ile karşılaşmaması, ne yazık ki haksız rekabete yol açmaktadır. Böylesi bir gerçeklik, bazen çalışanları kayıt dışı çalışmaya teşvik etmekte, hatta bazen de zorlamaktadir.

İstihdam kavramının sanayi devriminden başlayarak günümüze değin evrilmesi hem iş kavramının hem de istihdam konusunun farklı bağlamlarda incelenmesi gerekliliğini ortaya çıkarmıştır. İş kavramı bireylerin mevcut ihtiyaçlarını karşılayan ve istihdamın muhtemel karşılığı olarak ifade bulurken (Harvey- Krefting, 1985); sanayileşmenin bir etkisi olarak ücretli istihdama eş değer bir kavram olarak anılmıştır. Günümüzde ise, iş denildiğinde istihdamdan ziyade bir meslek kavramına dönülerek, iş bir sözleşmeden ziyade bireyin bütünleştiği bir olguya evrilmiştir (Toulmin, 1995). Dolayısıyla çalışma ücretli istihdamdan çok daha fazlası, katılım olanakları kısıtlı olan sosyo-politik bir ortamda çeşitli günlük faaliyetleri kapsayan bir olgu olarak tanımlanabilmektedir (Shaw \& Laliberte Rudman, 2009; Blank vd., 2015; Veiga-Seijo vd., 2017). Kavramın yansımasındaki bu tür bir geçiş, işsizlik ve istihdam kavramlarını daha kapsayıcı bir şekle sokarak, yalnızca resmi işgücü piyasasına katılma amacını gütme değil, aynı zamanda salt işgücü piyasası ile sınırlı olmayan dinamik ve sosyal bir süreç olarak tanımlanabilmektedir. Esasen benzer dönüşüm neoliberalizmin küresel anlamda yaygınlaşması ile işsizlik kavramının devletler tarafından daha ziyade kişisel bir sorun olarak makro yapılar, politikalar ve uygulamalar arasında çerçevelenmesi ile de örneklenebilir. Dolayısıyla işsizlik tam da bu noktada kayıt dışı çalışma şekillerini tercih eden işgücü ile iç içe geçmektedir. Kayıt dışı istihdam bir tercih olarak ele alınmakta ve salt işsiz olan bir bireyin tercihinden ziyade, işsiz kalma tehlikesi ile karşı karşıya olan kayıtlı çalışanları da kapsamaktadır.

Her ne kadar neoliberalizmin etkisi ile kayıt dışı istihdam açıklanmaya çalışılsa da Batı ve Doğu toplumlarındaki işsizlik sorunu aynı kayıt dışı istihdam kriterleriyle açıklanamaz. Batı'da işsiz kalma veya çalışamama işsizliği açıklarken, Türkiye özelinde düşük ücretle eksik istihdam edilenler kayıt dışı çalışmaya yönelmektedir. Ülkemiz özelindeki işsizlik rakamlarının yüksekliği ve eksik istihdam gerçeği, kayıt dışı istihdamın temel kaynağını oluşturmaktadır. Bu sebeple işsizlik kayıt dışı istihdam için bağımsız bir değişken olmakla beraberi kayıt dışı istihdamı oluşturan nedenlerinde ayrıca bir sonucudur (Güloğlu vd., 2003). Özellikle gelişmekte olan ülkelerin en önemli sosyal, ekonomik ve idari sorunlarının içerisinde yer alan kayıt dışı istihdamın başlıca nedenleri arasında nüfus artışı, iç/dış göç, gelir dağılımındaki makas arasındaki farkın adaletsiz artışı, işsizlik, enflasyon ve 
ekonomik yapıdaki değişim gibi nedenler sayılabilmektedir. Ayrıca, devletin etkin mali sistemi oluşturamaması da bu durumun ortaya çıkmasında belirleyici olmaktadır. Bunu destekler şekilde işsizliğin yol açtığı diğer ekonomik, sosyal ve bireysel düzeyde bazı maliyetler incelenerek kayıt dışı istihdama yol açan nedenler de incelenebilir. Kayıt dışı istihdam bu bağlamda çok kriterli bir yapıyı temsil eden ve aynı zaman farklı araştırma düzeylerinde disiplinler arası etkisi olan bir değişken özelliğgi taşımaktadır. Bu konular arasında; sosyal dışlanma ve özgürlüğün kaybedilmesi, beceri kaybı, intihar oranlarının artması ve psikolojik bazı etkiler, motivasyon kaybı, insan ilişkilerinin ve aile hayatında bozulmalar, rrk ve cinsiyet eşitsizliği ve bir takım sosyal değerler ve sorumluluğun kaybı gibi kapsamlı etkileri sayılabilir (Watts \& Mitchell, 2001).

Son yıllarda, kayıt dışılığı daha ayrıntılı anlamlandırmak ve refah üzerindeki bazı olumsuz etkilerini giderebilmek adına; Haziran 2015'te ILO 204 Sayılı kayıt dışı ekonomiden resmi ekonomiye geçişle ilgili tavsiye kararının, BM Sürdürülebilir Kalkınma Hedeflerinden, Hedef 8.3'ünde resmileştirmeye karşın doğrudan bir referansın dahil edilmesi ve ulusal olarak uygun sosyal koruma sistemleri ve önlemlerini uygulamaya yönelik küresel taahhütleri içeren Hedef 1.3 gibi yeni adımlar atılmıştır. Bu sayede, hükümetleri ve vergi mükelleflerini kayıt dışı ekonomi çalışanlarının korunmasına yatırım yapmaya ikna etmek üzerine ve kayıt altına alma konusunda politika yapıcı rehberliğe olan ihtiyaçtan bahsedilmektedir (OECD/ILO, 2019). Bunu başarabilmek için farklı kayıt dışılık kalıpları ve kalkınma sürecine katkısı hakkında derinlemesine bilgiye ihtiyaç vardır.

Bu çalışma ile kayıt dışı istihdama neden olan faktörlerin çok kriterli karar problemi altında incelenmesi uygun bulunarak, karşılıklı etkileşim içerisinde olduğu çoklu faktörlerin ve getirdiği maliyetlerin ölçümünün zor olması, kavramı oluşturan bir takım ana faktörler tarafından analiz edilmesi kararlaştırılmıştır. Bu sayede çalışanlar ve şirketler açısından konunun karmaşık yapısı daha öncelikli nedenlerin öne sürülmesi ile politika yapıcıların kayıt dışılığın üstesinden gelebilmeleri için farklı bir tespit niteliği taşımaktadır. Literatür taraması sonucunda kayıt dışı istihdam kavramının karmaşık yapısı sosyal, ekonomik, idari ve mali olarak üç ana boyutta ele alınmış olup, bu ana boyutlara ilişkin bir takım alt faktörler de incelenmiştir. Sosyal faktörlere ilişsin alt faktörler: nüfus artışı, işsizlik, emekli- dulyetim aylığı alanların istihdamı ve işgücünün niteliği; ekonomik faktörlere ilişkin alt faktörler: enflasyon, ekonomik krizler, gelir dağılımı ve ülkedeki küçük ve orta ölçekteki işletme sayısı; idari ve mali faktörlere ilişkin alt faktörler ise denetimin eksikliği, işgücü üzerindeki sigorta primi ve vergi yükü gibi kesintilerin yüksekliği, bürokrasinin fazlalığ1, çalışma hayatını düzenleyen bakanlıklar ve kurumlar arasındaki iletişim ve koordinasyon eksikliği olarak ele alınmıştır (Güloğlu vd., 2003; KADİM, 2006) Bu faktörler, çok kriterli karar verme yöntemlerinden olan DEMATEL ve Analitik A ğ Süreci (AAS) ile incelenmiştir. Kayıt dışı istihdama yol açan makro faktörlerden "ekonomik faktörler" en önemli ana faktör; "işsizlik" ise en önemli alt faktör olarak belirlenmiştir. Bu çalışmada ilk olarak kayıt dışı istihdam ile ilgili gerekli açıklamaların ardından, kayıt dışı istihdama neden olan faktörlerin analiz edildiği DEMATEL ve Analitik Ağ Süreci (AAS) yöntemlerinin açıklandığı araştırma metodolojisi bölümü yer almıştır. Daha sonra analizin gerçekleştirildiği uygulama bölümünde bulgular tartışılarak, sonuç bölümüyle çalışma noktalanmıştır. 


\section{Literatür Taraması}

Günümüzde iki milyar insanın kayıt dışı istihdamda olduğu gerçeğinden yola çıkılarak, çoğu insanın doğrudan veya dolaylı olarak kayıt dışı ekonominin bir parçası olduğu bilinmektedir. Esasen kayıt dışı ekonomi, farklı algılamalar ile de farklı şekilde tanımlanmaktadır. Bir grup insan, kayıt dışı istihdam içerisinde yer alan bireylerin, verimliliği düşük olan bir takım küçük işletmeleri çalıştırmaktan veya kötü çalışma koşulları, daha düşük ücret ve sosyal yardımlardan yoksun işlerde çalışmaktan başka seçeneği olmadığına inanmaktadır. Diğer bir grup ise; kayıt dışı istihdamı mevcut yasalara uymayan, kayıtlı ve kayıt dışı kuruluşlar arası haksız rekabet ile bağlantılı, vergi kaçakçılığı ile ekonomik ve sosyal kalkınmada bir engel olarak görmektedir. Başka bir grup ise kayıt dışı istihdamın kayıt altına alınmasıyla ticaret yapmaya hevesli işçiler olarak görmektedir. Dolayısıyla, kayıt dışılık farklı şekillerde yansımaktadır. Burada kati bir şekilde vurgulanmak istenen, kayıt dışılığın dünyadaki çoğu işçinin günlük yaşamının bir parçası olduğu ve beraberinde bazı riskler ve zaafları içermesidir. (OECD/ILO, 2019).

Uluslararası Çalışma Örgütü 2015 raporunda yer alan ifadelere göre kayıt dışı istihdam; ulusal çalışma mevzuatına, gelir vergisine veya sosyal korumaya hak kazanmaya veya belirli diğer istihdam yardımlarına (işten çıkarılma ön bildirimi, kıdem tazminatı, ödenen yıllık veya hastalık izni vb.) tabi olmayan fiili veya hukuki çalışma düzenlemelerini ifade etmektedir. İlgili raporda ele alınan kesimler çalışanlar, kendi hesabına işçilerle çalışan işverenler ve aile üyelerinden oluşan işçilerden oluşmaktadır. Çalışan, işvereni kendi adına sosyal güvenliğe katkıda bulunmuyorsa veya ücretli yıllık izin veya hastalık izninden yararlanmıyorsa kayıt dışı istihdam edilmiş sayılır. Bir işveren ve kendi hesabına çalışan bir işçi resmi bir kaydı veya defter tutma sistemi olmadan tüzel kişiliğe sahip olmayan bir işletme ise kayıt dışı istihdam içerisinde sayılmaktadır. Katkıda bulunan aile işçileri, kayıtlı veya kayıt dışı sektör işletmelerinde çalışıp çalışmadıklarına bakılmaksızın, tanımı gereği kayıt dışı istihdam edilmektedir (OECD/ILO, 2019).

Genelden hareket ile ülkemiz özelinde işgücü ve çalışma hayatından bir sapma olarak kayıt dışı istihdam tanımı yapmak gerekirse; sosyal güvenlik açısından, çalışanların sosyal güvenlik kurumuna hiç bildirilmemesi, prim ödeme gün sayılarının ya da prime esas kazanç tutarlarının aslında olduğundan eksik bildirilmesidir. Ayrıca kayıt dışı istihdam sürecini tanımlayan önemli unsurlardan biri de istatistiksel olarak ölçülmesinin zor olmasıdır. Kayıt dışı istihdam içinde yer alan kesimler ise genelde, işverenlerle birlikte, sendikal anlamda örgütlü olmayan, eğitim ve vasıftan uzak, pazarlık gücü bulunmayan çalışanlardır (Güloğlu vd., 2003; Mahiroğulları, 2017).

\subsection{Türkiye’de Görülen Kayıt Dışı İstihdam Şekilleri}

Kayıt dışı istihdam denilince akla gelen gereken sadece sigortasız çalışma olmamalıdır. Çünkü sigortalı çalışanlarda, yani kayıtlı istihdam olanlarda da kayıt dışılık söz konusu olabilmektedir. Örneğin; tam zamanlı çalışan kişilerin çalıştıkları gün/saat kadar değil de aslında olması gerekenden daha az prim ödeme gün sayısı kadar Sosyal Güvenlik Kurumu (SGK)'na bildirilmesi ya da sigortalı çalışan kişinin hak ettiği ve aldığı ücret 
üzerinden değil de ödenen prim ödeme maliyetlerini azaltmak için hak ettiği ücretten daha azı tutarında SGK' ya bildirilmesi de SGK açısından kayıt dışılık sayılmaktadır (SSK, 2000; SSK, 2001).

Kayıt dışı istihdam diğer gelişmekte olan ülkelerde olduğu gibi Türkiye için de önemli sorunlarından birisidir. Kayıt dışı istihdam ile mücadele için hem SGK hem de Aile, Çalışma ve Sosyal Hizmetler Bakanlığı bünyesinde denetim ve kontrolle görevli memurlar bulunmaktadır. Bu görevli kişiler sahada kayıt dışı istihdam ile mücadele etmek için mahalli denetimler gerçekleştirmektedirler (KADİM, 2006).

Ayrıca kayıt dışı istihdamla mücadele için kamu kurum ve kuruluşlarıyla SGK'nın imzalamış olduğu birtakım protokoller kapsamında kamu kurum ve kuruluşlarından gelen listeler, belgeler veya diğer belgeler ile kayıt dışı istihdam edilen kişilerin tespit edilmesi sağlanmaktadır. Örneğin, bankadan kredi çekmek isteyen çalışan bankaya maaş bordrosu vermekte, kredi çeken bu kişilerin listesi de SGK'ya gönderilerek ilgili servis tarafından gerekli kontrol sağlandıktan sonra, kişinin sigortasının olmaması durumunda sigortasının sağlanarak kayıt dışı istihdam şeklinde istihdam edilen kişi kayıt altına alınmaktadır (SGK, 2015).

Kayıt dışı olma durumunu azaltmak için teşviklerin artırılması, işveren üzerindeki sigorta maliyetleri azaltılması hedeflenmektedir. Bu kapsamda hem SGK'nın hem de diğer kurumların (İş-Kur, Ekonomi Bakanlığı, vb.) mevzuatlarında birçok teşvik uygulanmaktadır. $\mathrm{Bu}$ teşviklerin bir kısmı sigorta primlerinin maliyetlerini azaltmaya yönelikken, bir kısmı ise ekstra çalışan alarak istihdam sayısını artırmaya yöneliktir. Örneğin primlerini düzenli ödeyen ve SGK'ya borcu bulunmayan işverenler 5510 Sayılı Kanun'un 81. maddesi 1. fıkrasının i bendi bahsi geçen $\% 5$ puanlık işveren teşvikinden yararlanılarak kişiyi istihdam etmesinden dolayı katlandığı sigorta primi maliyetini azaltmaktadır. Ayrıca işverenler SGK'ya ödedikleri işçilik giderlerini mali açıdan gider olarak göstererek daha az vergi ödeme şansına sahip olmaktadırlar.

\subsection{Kayıt Dışı İstihdam Oranları}

ILO’nun, 2017 yılı TÜİK Hane halkı İşgücü Anketi verilerini kullanarak Türkiye'deki Suriyeli işçilerin işgücü piyasası durumuna ilişkin yaptırdığı çalışmada, 2017 yılı itibariyle çalışma çağındaki 2 milyon Suriyeli'den 930.000'inin işgücüne dahil olduğunu ve 813.000'inin büyük ölçüde kayıt dışı istihdam edildiğini ortaya koymaktadır. Suriyeliler için en çok istihdam edilen üç sektör; (1) hazır giyim endüstrisi, (2) ticaret ve konaklama ve (3) diğer imalat sektörü olarak gerçekleşmiştir. Bununla beraber, Suriyeli işçilerin İstanbul ve Türkiye'nin güneydoğusunda yoğunlaştığı ve çoğu işçinin uzun saatler çalışmak zorunda kaldığı (\%75'i yasal haftalık çalışma süresi olan 45 saatten fazla çalıştı) ve asgari ücretin altında kazandıkları ortaya çıkmıştır. Cinsiyet önemli bir farklılık olarak ortaya çıkarak Suriyeli kadınlar erkek meslektaşlarından neredeyse \%20 daha az ve asgari ücretin yaklaşık $\% 25$ altında kazandıkları belirtilmiştir. Bu durum Türkiye genelindeki kayıt dışı istihdam kavramını farklı bir boyuta taşımıştır. 
Aşağıdaki Tablo 1'de 2002 yılından 2019 yılına kadar tarım, tarım dışı, sanayi, hizmet, inşaat sektörleri ile genel kayıt dışı istihdam oranları gösterilmektedir.

Tablo: 1

\section{Sektörlere Göre Kayıt Dışı İstihdam Oranları (\%)}

\begin{tabular}{|c|c|c|c|c|c|c|}
\hline Yillar & Tarım & Tarım Dışı & Sanayi & Hizmet & İnşaat & Genel \\
\hline 2002 & 90,14 & 31,74 & 36,4 & 29,19 & - & 52,14 \\
\hline 2003 & 91,15 & 31,55 & 36,43 & 29,00 & - & 51,75 \\
\hline 2004 & 89,90 & 33,83 & 37,28 & 31,96 & - & 50,14 \\
\hline 2005 & 88,22 & 34,32 & 38,11 & 32,27 & - & 48,17 \\
\hline 2006 & 87,77 & 34,06 & 38,12 & 31,88 & - & 46,97 \\
\hline 2007 & 88,14 & 32,34 & 35,51 & 30,63 & - & 45,44 \\
\hline 2008 & 87,84 & 29,76 & 31,61 & 28,77 & - & 43,50 \\
\hline 2009 & 85,84 & 30,08 & 33,43 & 28,4 & - & 43,84 \\
\hline 2010 & 85,47 & 29,06 & 32,68 & 27,11 & - & 43,25 \\
\hline 2011 & 83,85 & 27,76 & 31,50 & 25,71 & - & 42,05 \\
\hline 2012 & 83,61 & 24,51 & 27,89 & 22,73 & - & 39,02 \\
\hline 2013 & 83,28 & 22,40 & 25,23 & 20,90 & - & 36,75 \\
\hline 2014 & 82,27 & 22,32 & 20,26 & 21,09 & 36,61 & 34,97 \\
\hline 2015 & 81,16 & 21,23 & 19,13 & 20,05 & 35,58 & 33,57 \\
\hline 2016 & 82,09 & 21,72 & 20,2 & 20,35 & 35,76 & 33,49 \\
\hline 2017 & 83,33 & 22,10 & 20,03 & 20,95 & 35,8 & 33,97 \\
\hline 2018 & 82,73 & 22,28 & 20,29 & 21,46 & 34,39 & 33,42 \\
\hline 2019 & 86,62 & 22,96 & 20,03 & 22,55 & 37,74 & 34,52 \\
\hline
\end{tabular}

Kaynak: Türkiye İstatistik Kurumu'nun Hane halkı İşü̈cü İstatistiklerinden faydalanılarak Sosyal Güvenlik Kurumu tarafindan kendi sitesinde derlenmiştir.

Tablo 1'de görüldüğü üzere tarım sektörünün kayıt dışı istihdam oranları içerisinde oldukça geniş bir kısmını oluşturduğu söylenebilir. Kentleşme, göç, mevsimlik iş vb. faktörlerin, tarımdaki kayıt dışılığı etkilediği bilgisi dahilinde belirtilen tarım sektörü oranları gelişmekte olan ülkeler bağlamında ve kayıt dışı istihdamın farklı farklı kavramlaştırılması göz önüne alındığında, yanıltıcı olabilmektedir. Türkiye'de görece azalan bir trend izlemesi, tarım sektöründeki küçülmeye, köyden kente olan göçlere, ücretsiz istihdamın azalması gibi faktörlerle açıklanabilmektedir. Bu açıdan bakıldığında, kayıt dışı istihdamın ilk olarak tarımsal olmayan işgücü şeklinde tanımlanması ile bağdaşan, fakat geçerliliği konusunda uzlaşılamayan bir kavram olma statüsünü vurgulayan bir bulgu olarak karşımıza çıkmaktadır. Hangi bağlamda incelenirse incelensin, tarım sektörü bu anlamda, Türkiye'de kayıt dışı istihdam denildiğinde halen en önde gelen istihdam sektörü olduğu açıkça görülmektedir.

Türkiye genelinde araştırma özelinde uzman görüşü alınan BEBKA bölgesinde yer alan, sanayileşme ve göç alma faktörlerinden etkilenen Eskişehir ilinde 2019/01-09. dönemler 4/a (SSK) kapsamında aktif çalışan sayıları (Tablo 2) ve Tablo 3'te Bursa, Eskişehir, Bilecik illerinde kayıt dışı istihdam oranları verilmiş olup sayıların zaman içerisinde dalgalandığ 1 görülmektedir.

Tablo: 2

Eskişehir İlinde 2019/01-09. Dönemler 4/A(SSK) Kapsamında Aktif Çalışan Sayıları (Aktif Sigortalılar Kategorisi; Kişi Bazında İç Anadolu Bölgesi, Eskişehir Rakamları)

\begin{tabular}{|c|c|c|c|c|c|c|c|c|c|}
\hline Gösterge & $\mathbf{2 0 1 9 . 0 1}$ & $\mathbf{2 0 1 9 . 0 2}$ & $\mathbf{2 0 1 9 . 0 3}$ & $\mathbf{2 0 1 9 . 0 4}$ & $\mathbf{2 0 1 9 . 0 5}$ & $\mathbf{2 0 1 9 . 0 6}$ & $\mathbf{2 0 1 9 . 0 7}$ & $\mathbf{2 0 1 9 . 0 8}$ & $\mathbf{2 0 1 9 . 0 9}$ \\
\hline Sigortal, Aktif, Toplam (4a) & 177.575 & 177.762 & 182.558 & 183.109 & 183.906 & 187.107 & 184.100 & 179.511 & 185.135 \\
\hline Sigortali, Aktif, Zorunlu Sigortalı (4a) & 162.427 & 162.503 & 166.604 & 166.927 & 167.823 & 167.711 & 168.730 & 166.728 & 170.410 \\
\hline
\end{tabular}

Kaynak: SGK tarafindan derlenmiştir. 
Tablo: 3

\section{Bursa, Eskișehir, Bilecik Bölgesi’ne Göre Kayıt Dıșı İstihdam Oranları (\%)}

\begin{tabular}{|c|c|c|c|c|c|c|c|c|c|c|c|}
\hline BÖLGE & $\mathbf{2 0 0 9}$ & $\mathbf{2 0 1 0}$ & $\mathbf{2 0 1 1}$ & $\mathbf{2 0 1 2}$ & $\mathbf{2 0 1 3}$ & $\mathbf{2 0 1 4}$ & $\mathbf{2 0 1 5}$ & $\mathbf{2 0 1 6}$ & $\mathbf{2 0 1 7}$ & $\mathbf{2 0 1 8}$ & $\mathbf{2 0 1 9}$ \\
\hline Bursa, Eskişehir, Bilecik & 29,91 & 28,42 & 28,05 & 23,67 & 24,55 & 20,41 & 20,44 & 19,86 & 22,73 & 23,36 & 25,36 \\
\hline
\end{tabular}

Tablo 3 verilerindeki kayıt dışı istihdam artışı Suriye'den gelen göç ve çeşitli sektörlerde istihdam edilmeleriyle dolaylı olarak açıklama bulabilir. Türkiye'de kayıt dışı istihdamın TÜİK verilerine göre halen \%33'lerde olması, sosyal güvenlik sistemi bağlamında önemli bir sorun olduğunun göstergesidir. Türkiye'deki sosyal güvenlik sisteminin sürdürülebilir olmasının en büyük engellerinden biri olan kayıt dışı istihdamın önüne geçebilmek için kurumsal anlamda tedbirler alınması gerekmiştir. Bu sebeple 2011 yılında Sigorta Primleri Hizmetleri Genel Müdürlüğü bünyesinde, Kayıt Dışı İstihdam Daire Başkanlığ̣ kurulmuştur. Ayrıca 2011 yılında Sosyal Güvenlik Denetmenliği kadroları ihdas edilerek kayıt dışılığı azaltmaya yönelik adımlar atılmaya devam edilmiştir. Bu meslek grubu oluşturulmasındaki amaç ise merkezden kayıt dişı istihdama yönelik denetimlerin gecikmeli ve zor olmasıdır. Bu sebeple, taşra kadroları ile kayıt dışı istihdamda azalma sağlanması hedeflenmiştir. Bu kadro ihdası ile görüldüğü gibi Tablo 1'de kayı1 dışı istihdam oranlarında artıştan ziyade stabil durum gözlemlenebilmektedir. Yaşanan sosyal ve ekonomik koşullar nedeniyle kayıt dışı istihdama yönelik azalmanın son yıllarda yavaşladığı verilerden çıkarılabilecek bir diğer bulgudur.

\subsection{Kayıt Dışı İstihdamı Oluşturan Faktörler}

Kayıt dışılık gelişmiş ve bir dereceye kadar gelişmekte olan ülkelerde bir norm olsa da gayri resmi faaliyetlerin farklılığı ve çeşitliliğgi, kayıt dışılığın altta yatan nedenler ve devletlerin izlemesi gereken politikalar hakkında çeşitli perspektifler ortaya çıkarmaktadır. OECD/ILO 2019 raporunda kayıt dışılığı oluşturan faktörlerin yapısal (örn. emek fazlası ve artan küresel rekabetin yarattı̆̆ baskı), yasal ve kurumsal (örn. düzenlemeler, vergiler ve zayıf yaptırımlar) ya da davranışsal (örn. firmaların ve hane halkının kayıtlı ya da kayıt dışı olma kararını yasal olmanın, farkındalık ve güvenin faydalarını değerlendirerek verdikleri belirtilmektedir) olarak yer almaktadır. Bu durum farklı ülkelerde farklı faktörler tarafından etkilenmektedir. Ülkemiz örneğinde istihdam yapısında farklı özelliklerin yer aldı̆̆ görülmektedir ki, düşük ücretli kamu çalışanlarına, yeterli maaş alamayan emeklilere, gelirini yükseltme konusunda kayıt dışı istihdam bir kaynak oluşturabilmektedir (Güloğlu vd., 2003).

Literatür incelendiğinde kayıt dışı istihdama yönelik birçok araştırmanın yapıldı̆̆ 1 , bu araştırmalarda kayıt dışı istihdama neden olan faktörler farklı ana boyut ya da alt boyutlar şeklinde teorik olarak ele alındığı görülmüştür. Mahiroğulları (2017) tarafından kayıt dışına neden olan faktörler teorik olarak incelenmiştir. Bu faktörler; ekonomik nedenler, sosyal nedenler (hızlı nüfus artışı, kırsal kesimden kente göçün sürmesi, yabancı kaçak işçilik, işgücünün niteliği, eğitim ve bilinç seviyesinin yetersizliği) ve işgücü üzerindeki sigorta primi ve vergi yükü gibi kesintilerin yüksekliği olarak belirtilmiştir. Fidan \& Genç (2013) tarafından yapılan çalışmada ise kayıt dışına neden olan faktörler; sosyal nedenler (nüfus artışı, işsizlik, göç, kentleşme, emekli-dul-yetim aylığı alanların istihdamı), ekonomik 
nedenler (enflasyon, ekonomik krizler, rekabet gücü, sektörel yapı, gelir dağılımı), idari ve mali nedenler (vergi sistemi, denetim eksikliği, vergi yükü, siyasal yapı) olarak belirtilmiştir (Aydemir; 1994; Toptaş, 1998).

Dam vd. (2018) çalışmasında ise kayıt dışına neden olan faktörler; ekonomik ve mali nedenler (enflasyonist ortamlar, tarım kesimin ekonomi içerisindeki payı, gelir ve kaynak dağılımındaki adaletsizlik, ülkedeki küçük ve orta ölçekteki işletme sayısı, küçük işletmelerin rekabet güçleri, vergi sistemleri, mali denetimin eksikliği, ağır vergi yükü, siyasal yapı); sosyal ve kültürel nedenler (demografik yap1, göç artış1, çarpık kentleşme, nüfus artışı, eğitim ve sağlık sistemi); idari ve bürokratik nedenler(bürokrasinin fazlalığı, vergi ve sosyal güvenlik mevzuatının uzun ve karmaşık yapısı ve sıklıkla değişmesi, etkili ve düzenli denetim faaliyetinin olmaması, çalışma hayatını düzenleyen bakanlıklar ve kurumlar arasındaki iletişim ve koordinasyon eksikliği, bireylerin vergi ödeme bilinci, tahsil edilen vergilerin uygun olarak kullanılmadığı yönünde oluşan alg1 veya bireylerin kamu idaresine olan güvensizlik duygusu) olarak ayrımlaştırılmıştır.

Literatür örneklerinde belirtilen değişkenler genelde makro değişkenlerdir (Schneider \& Enste, 2000; Feld \& Schneider, 2010). Kayıt dış1 istihdamın, kayıt dışı ekonominin bir uzantısı olduğu düşünüldüğünde belirli bir form almış bir yapı olduğu görülmektedir. Bu yapı hem makro hem de mikro bazı faktörlerden oluşmaktadır (Hazans, 2011; Fialova \& Schneider, 2011). Bununla birlikte ister makro ister mikro bakış açısı ile yapılsın, yapılan her çalışma ülkemiz özelinde büyük bir problem teşkil eden kayıt dışı istihdam konusunu aydınlatıcı olacaktır. Kayıt dışı istihdam aynı zamanda, çalışan-işveren kutuplaşması ve bilgi asimetrisi ile de açıklanabilmekte, ancak analiz birimi ne olursa olsun, her tür değişkenin bir diğerini etkilediği çok katmanlı bir toplumsal yapı olduğu şüphe götürmemektedir (Heritage Foundation, 2011). Makro faktörlerin ele alındığ 1 bu çalışma ile çok kriterli bir problem olan kayıt dışı istihdam yapısı analiz edilmiş olup, politika yapıcılar ve uygulayıcılara bilgi sağlayıcı olması hedeflenmiştir. Literatürde genelde kayıt dışı istihdamı etkileyen faktörler teorik olarak ele alınmıştır. Bu çalışmada ise Güloğlu vd.'nin (2003) çalışması temel alınarak, kayıt dışı istihdamı etkileyen faktörler; sosyal, ekonomik, idari ve mali faktörler olarak, alınarak ülkemiz özelinde nicel olarak DEMATEL tabanlı AAS yöntemi ile incelenmiştir. Bu yöntemin seçilmesinin nedeni faktörler arası ilişkileri kullanarak bu faktörleri önem düzeylerine göre ağırlıklandırmaktır. Literatürde çok çeşitli uygulama alanlarında DEMATEL-AAS bütünleşik yöntemiyle yapılmış çalışmalara rastlanmaktadır. Ancak kayıt dışı istihdam ile ilgili ÇKKV yöntemleri ile yapılmış bir çalışmaya rastlanılmamıştır. Kayıt dışı istihdamı etkileyen faktörlere ve bu faktörlerin açıklamalarına aşağıda yer verilmiştir.

\section{Sosyal Faktörler (F1)}

Ülkenin sahip olduğu eğitim ve sağlık sistemi, demografik yapısı, göç, kentleşme ve diğer makro faktörler kayıt dışı istihdamı etkileyen sosyal faktörler arasında yer almaktadır. 


\section{Nüfus Artışı (F11)}

Hızlı artan bir nüfus emek arzının fazlalığı ve dolayısıyla işgücü piyasasının istihdam olanaklarının yetersizliği anlamına gelmektedir. Bu durum, daha az gelir ile ve sosyal güvenceye sahip olmadan çalışmaya razı bir kayıt dışı grubun varlığı anlamına gelmektedir (Us, 2004). Nüfusun demografik yapısı da dolaylı olarak kayıt dışı istihdamı etkileyen faktörleri içermektedir (yabancı işçilerin oranı, çocuk sayısı ve çalışma oranları, kadın erkek oranı ve istihdama katılma yüzdeleri vb.)

\section{İșizizlik (F12)}

İşsizlik birçok nedene bağlı olmakla birlikte, bir kontrata bağlı olmadan çalışarak resmi kayıtlı istihdamın dışında yer almaktadır (Taylor, 1996). İşsizlik ödeneği bağlamında işsizlik sırasında sağlanan daha yüksek gelir, baskıyı ve kayıt dışı işi kabul etme isteğini azaltır ve işsizlerin kayıtlı işgücü piyasasında daha iyi bir eşleşme için daha uzun bir arama yapabilmesini sağlar. Küreselleşme bir bakıma işsizliği yapısal bir problem haline getirerek, kayıt dışı istihdamı artırıcı bir etki yapmıştır. Köyden kente olan göçler de işsizliği olumsuz etkilemiştir. Gelişmekte olan ülkelerde işgücü maliyetleri, işsizlik oranını artırabilmektedir. Belirtilen nedenlerle, işsizliğin bir ülkenin önemli sosyoekonomik faktörlerinden biri olması muhtemeldir. İşsizlik ne kadar azalırsa, kayıt dışı istihdam da o denli azalacaktır (Mahiroğulları, 2017).

\section{Emekli Dul Yetim Aylığı Alanların İstidamı (F13)}

Sosyal kurumlardan işsizlik maaşı veya emekli, dul ve yetim aylığı alanlar, gelirlerinin kesintiye uğramaması için kayıt dışı istihdam yanlısıdırlar. Ancak asgari ücret artış1, kişileri resmi bir iş bulmaya itebilmektedir.

\section{İşgücünün Niteliği (F14)}

Eğitim ve sağlık yapısı bir ülkedeki işgücü niteliğini belirleyen sosyal faktörlerdendir (Galiani \& Weinschelbaum, 2012). Bununla birlikte, köyden kente göç eden veya mültecilerin sayısının artması gibi olgular, işgücü niteliğini etkileyebilir. Bu durum, sektörden sektöre değişiklik göstermektedir. Özellikle tarım sektörü ve giderek ekonomideki payının azalması, işgücünün kentlere göç etmesine neden olmuştur. Bu sebepten, resmi ekonomi içerisindeki nitelikli işgücü tanımının dışında, kayıt dışı istihdam grubu içerisinde yer almışlardır. Böylesi bir durumda, niteliksiz işgücü daha az kayıtlı işgücünü veya kendisine tanınan işsizlik ödeneğini daha çok tercih eder bir durum sergiler olabilir.

\section{Ekonomik Faktörler (F2)}

Ekonomik faktörler bir ülkenin kayıt dışı istihdamını açıklamada önemli bir rol oynamaktadır. Ekonomik sistemin baskısı, bireylerin ve işletmelerin daha fazla kazanma istekleri, kayıt dışılığa itebilmekte ve bu durum sektörden sektöre değişmektedir. 


\section{Enflasyon (F21)}

Resmi veya kayıt altında olan sektörlerde ücretler üzerindeki enflasyon baskısı muhtemelen daha güçlü olmakta ve bu durum kayıt dışı emeğin marjinal bir birimini, resmi ikamesine göre daha ucuz hale getirmektedir. Buna ek olarak fiyat kontrolleri, gayri resmi işletmeler aracilığıyla bu durumdan kaçınmak için bir çeşit teşvik unsuru görür. Hükümetlerin enflasyon ve fiyat konusundaki sıkı kontrolleri, bireyleri ve işletmeleri mutsuzluğa sevk ederek, güven olgusunu zedelemektedir.

\section{Ekonomik Krizler (F22)}

Ekonomik krizler (ekonomik değişkenler arasında diğer değişkenler tarafindan etkilenen bir boyut olup, covid-19 pandemisi vb.), kayıt dış1 istihdamı tetiklemektedir. Özellikle enflasyonun olduğu ortamlarda, gelecekle ilgili belirsizlikler, satın almayı, yatırımı ve istihdam kararlarını olumsuz bir etkileyerek, kayıt dışı istihdamı artırıcı bir sonuç yaratmaktadır (Watts, 2000).

\section{Gelir Dağılımı (F23)}

Gelir eşitsizliği devletin kurumsal kalitesinin düşük olmasından kaynaklı olduğunda, yoksul bireylerin, kayıt dışı istihdam ile daha az üretken olmalarına rağmen, üretim çıktılarını elde edebilmelerinin kendilerinin faydasına olduğu görüşü hâkim olmaktadır. Böylece gelir eşitsizliği ile kayıt dışı istihdam arasında bir ilişki ortaya çıkmaktadır (Chong $\&$ Gradstein, 2007). Yoksul bireylerin, kayıtlı istihdam bağlamında hem üretkenlik eşiğinin hem de serbest gelir eşiğinin altına düşme olasılıkları daha yüksektir. Yüksek gelir eşitsizliğinin, devletin bir grubun çıkarlarını koruduğu algısı yaratarak, vergi motivasyonunu düşürdüğü ve kayıt dışılığı artırdığı belirtilmektedir (Perry vd., 2007, Dreher \& Schneider, 2010). Bu durum, vergilerin etkinliği ve verimliliğini düşürmekte, dolaylı olarak devletin hizmet kalitesini de düşürmektedir. Bu sebepten, orta sınıf genelinde vergi için ödenen bedelin değeri düşmekte ve kayıt dışı istihdam artmaktadır.

\section{Ülkedeki Küçük ve Orta Ölçekteki İşletmeler (F24)}

Ülke içindeki küçük ve orta ölçekteki işletmelerin sayısı (özellikle Türkiye), küçük işletmelerin rekabet içindeki konumları ve istihdam içerisindeki yerleri önem arz etmektedir. Sosyal güvenlik kurumu bağlamında prim ödeme güçlükleri, bazı kredilere ulaşamama, kayıt dışı istihdamı artırıcı rol oynamaktadır. Uluslararası yapıda olan büyük işletmelerin genellikle kapsamlı denetimlere tabi oldukları düşünüldüğünde, kayıt dışı işgücü kullanma olasılıkları küçük ve orta ölçekteki işletmelere kıyasla daha düşük olduğu söylenebilir. Bu sebepten, bir ülkenin yatırım ortamının olumlu olması, doğrudan yabancı yatırımı artırarak kayıt dışı istihdam payını daha da azaltıcı olacağı beklenmektedir. Ayrıca, büyük işletmelerin diğerlerine göre daha yüksek ücret ve koşullar sağlaması, kayıtlı ekonomi bağlamında istihdamı kendine çekmektedir. Bu durum küçük ve orta boyuttaki işletmelerin çoğunluk olduğu bir ülkede, denetimin daha çok küçük işletmelere kayması düşüncesini destekler niteliktedir. 


\section{İdari ve Mali Faktörler}

Artan vergi yükü, iş gücü piyasası düzenlemeleri, kamu mal ve hizmetlerinin kalitesi ve kayıt altındaki ekonominin durumu kayıt dışı ekonominin itici güçleri arasında sayılabilmektedir. Vergi yükünü azaltmak mali bir politikadır ve kayıt dışılığı azaltmak için iyi politikalar önem arz etmektedir. Ekonomik ve mali sistemin iç içe çalıştığ hatırlanmalıdır.

\section{Denetimin Eksikliği (F31)}

Vergi ve sosyal güvenlik mevzuatı ile çalışma hayatını düzenleyen kanunların uzun ve karmaşık yapısı denetim mekanizmalarının etkin olarak kullanılmasını gerekli kılmaktadır. Sıklıkla değişen kanunlar, sadece işçi ve işvereni değil, denetim konusunun uzmanlarını dahi zorlayan bir konu olmaktadır. Denetim, etik dışı faaliyetin karşıı çözümü olarak düşünüldüğünde; kurumlaşmış bir etik dışı sistemin varlığını da kabul etmeyi meşru kılar. Dolayısıyla denetimin eksik olmasının kayıt dışı istihdama sebep olan bir faktör olarak düşünülmesi aslen başlı başına bir problemdir (Özşuca \& Gökbayrak, 2012). Bunun yanında, işletmelerin geçmiş dönemlerinde yapmış oldukları işlemlerin etkin şekilde denetlenmemesi kayıt dışı ekonomik faaliyetlerin de artışını hızlandırabilir. Böylesi bir problem, eğitim ile kati bir çözüme ulaşacağı gibi (bilinç düzeyinin artması, etik eğitiminin yaygınlaşması vb.) uzun bir sosyo-kültürel değişimin bir parçası olarak gerçekleştirilebilir. Hali hazırda, denetim kuruluşlarının teknolojik altyapılarının birleştirilmesi ile denetleyici görevi bulunan kurumların koordinasyonunun sağlanması ile çözümlenmeye çalışılmaktadır. Sivil toplum kuruluşları da bireyler ve işletmeler ile eş anlı çalışarak kayıt dışı istihdam kontrol altında tutulabilir. Ancak, bireyin bu anlamdaki öz denetimi, devlet eliyle yapılan ve cezai yaptırımlarla caydırıcı olmasından daha etkin olacağı düşünülebilir.

\section{İşgücü Üzerindeki Sigorta Primi ve Vergi Yükü (F32)}

Neredeyse tüm çalışmalarda, toplam vergi ve sosyal güvenlik katkı yükünün kayıt dışı ekonominin varlığının temel nedenleri arasında olduğu saptanmıştır (Shneider vd., 2010) Vergiler emek-eğlence tercihlerini etkilediğinden ve gölge ekonomisinde işgücü arzını teşvik ettiğinden, genel vergi yükünün bozulması ekonomistler için önemli bir sorundur. Resmi ekonomideki toplam işgücü maliyeti ile vergi sonrası kazançlar (işten) arasındaki fark ne kadar büyük olursa, bu farktan kaçınma ve kayıt dışı ekonomide çalışma teşviki de o kadar büyük olur. Bu fark büyük ölçüde sosyal güvenlik yüküne / ödemelerine ve genel vergi yüküne bağlı olduğundan, ikincisi varlı̆̆ın ve gölge ekonomisinin artmasının temel özellikleridir.

\section{Çalışma Hayatını Düzenleyen Bakanlıklar ve Kurumlar (F34)}

Düzenlemelerin yoğunluğunun artırılması, kayıtlı ekonomi içerisinde yer alan bireylerin seçim özgürlüğünü azaltan bir diğer önemli faktördür. Düzenlemeler, işgücü piyasası düzenlemelerini (örn. Asgari ücret veya işten çıarmaya karşı koruma), ticaret engellerini (örneğin ithalat kotaları) ve yabancılar için işgücü piyasası kısıtlamalarını (örneğin, yabancı işçilerin serbest dolaşımına iliş̧kin kısıtlamalar) içerir (Casson vd., 2010). 
Düzenlemeler, kayıtlı ekonomilerde işgücü maliyetlerini artırıcı bir etki yapmaktadır. $\mathrm{Bu}$ maliyetlerin çoğu çalışanlara kaydırılabileceğinden, kayıt dışı istihdamı teşviki edici fakat aynı zamanda kaçınılması gereken bir maliyet unsuru olarak da görülür. Yapılan araştırmalar genel düzenleme oranı arttıkça, Gayri safi milli hasıla içerisindeki kayıt dışılığın arttığını desteklemektedir (Johnson, vd., 1997; Johnson, vd., 1998). Çalışmalar her düzenlemenin ölçüsünün, hayıt dışı ekonominin payı ile pozitif ve olumlu ilişkili olduğudur. Dolayısıyla, hükümetler bu oranı artırmak yerine, yasa ve düzenlemelerin uygulanması ve iyileştirmesine daha çok önem vermeleri gerektiğini göstermektedir.

\section{Bürokrasinin Fazlalığı (F33)}

Bürokrasi, çalışma hayatını düzenleyen yasa ve kurumlar ile direkt ilişsilidir. Bununla birlikte, bazı hükümetler kayıt dışı ekonomiyi azaltmaya çalışırken (daha fazla düzenleme ve yasa), kamu sektöründe istihdamın artışına ve çoğunlukla bürokratların gücünün artmasına neden olabilir (Langbein \& Knack, 2010). Politika yapıcılığın belirtilen sebeplerden ötürü bazı hükümetler tarafından tercih edilebilirliğini ve uygulanabilir olmasını kolaylaştırmaktadır (Frey \& Weck,1983; Jonasson, 2012).

\section{Araştırma Metodolojisi}

Bu çalışmada faktörler arasındaki etki yapısını ortaya koyabilmek için DEMATEL yöntemi kullanılmıştır. Her faktör arasındaki etki yapısı ortaya konduktan sonra en önemli faktörleri belirlemek amacıyla tüm faktörler AAS yöntemi ile ağırlıklandırılmıştır. Dolayısıyla, değerlendirme çerçevesi iki ana aşama içermektedir: (1) DEMATEL tekniğini kayıt dışı istihdama neden olan faktörler arasında etki-ilişkiler haritasının oluşturulması, (2) Etki ilişkiler haritasına dayalı AAS'yi birleştirerek her faktörün ağırlığının hesaplanmasıdır.

\subsection{DEMATEL}

DEMATEL (The Decision Making Experiment and Evaluation Laboratory) yaklaşımı, 1973 yılında Cenevre'de, karmaşık kriterler arasındaki etki faktörlerini analiz etmek için yapısal bir model oluşturmak ve analiz etmek için genişletilmiş bir yaklaşımdır (Muhammad \& Cavus, 2017; Shieh vd., 2010).

DEMATEL metodolojisi aşağıda özetlenmiştir (Fontele \& Gabus, 1976; Wu, 2008):

\section{Adım 1: Direkt İlişki Matrisinin Oluşturulması}

$x_{i j}^{k}$ Tam sayı skoru k. uzman tarafından verilmektedir. Bu skor i. kriterin j. kriter üzerindeki etki seviyesini gösterir. nxn'lik matris olan A, Eşitlik 1'de gösterildiği gibi uzmanların bireysel skorlarının ortalaması alınarak hesaplanmaktadır. Kullanılan DEMATEL ikili karşılaştırma ölçeği ise Tablo 4'te verilmiştir.

$$
a_{i j}=\frac{1}{H} \sum_{k=1}^{H} x_{i j}^{k}
$$


H: Toplam uzman sayıs1

Tablo: 4

DEMATEL İkili Karşılaştırma Ölçeği (Shieh vd., 2010)

\begin{tabular}{|c|c|}
\hline Sayısal Değer & Tanım \\
\hline 0 & Etkisiz \\
\hline 1 & Düşük Etki \\
\hline 2 & Orta Etki \\
\hline 3 & Yüksek Etki \\
\hline
\end{tabular}

\section{Adım 2: Normalize Edilmiş Direkt İlişki Matrisinin Oluşturulması}

Normalize edilmiş direkt ilişki matrisi (X)Eşitlik 2 yardımıyla direkt ilişki matrisi (A) kullanılarak elde edilmektedir.

$$
\begin{aligned}
& X=k \cdot A \\
& k=\frac{1}{\max \sum_{\substack{j=1 \\
i \leq i \leq n}}^{n} a_{i j}}, \quad i, j=1,2, \ldots, n
\end{aligned}
$$

\section{Adım 3: Toplam Etki Matrisinin Oluşturulması}

Toplam etki matrisi $\left(T_{C}\right)$, Eşitlik 4 yardımıyla normalize edilmiş direkt ilişki matrisi (X) kullanılarak elde edilmektedir. I birim matrisi ifade etmektedir.

$$
T_{C}=X(I-X)^{-1}
$$

\section{Adım 4: Nedensel Diyagramın Elde Edilmesi}

Satırların ve sütunların toplamı ayrı ayrı vektör $\mathrm{R}$ ve vektör $\mathrm{C}$ olarak Eşitlik 5 ve Eşitlik 6 kullanılarak hesaplanmaktadır. Daha sonra, "önem” olarak adlandırılan yatay eksen $(\mathrm{C}+\mathrm{R})$, ölçütün ne kadar önemli olduğunu ortaya koyan C'ye R eklenerek yapılmaktadır. Benzer şekilde, “ilişki” adlı dikey eksen (C-R), C'yi R'den çıkararak yapılmaktadır.

$$
\begin{aligned}
& T=\left\lfloor t_{i j}\right\rfloor_{n x n}, i, j=1,2, \ldots, n \\
& C=\left[\sum_{j=1}^{n} t_{i j}\right]_{n x 1}=\left[t_{i}\right]_{n x 1} \\
& R=\left[\sum_{i=1}^{n} t_{i j}\right]_{1 x n}=\left[t_{j}\right]_{1 x n}
\end{aligned}
$$




\subsection{AAS}

Bu bölümde, Bütünleştirilmiş DEMATEL-AAS yöntemi için DEMATEL'in toplam etki matrisi AAS'nin süper matrisine dönüştürülür. AAS metodolojisi aşağıda özetlenmiştir (Hwang vd., 2014):

\section{Adım 5: Normalize Edilmiş Direkt Etki Matrisinin Oluşturulması}

Toplam etki matrisi $\left(T_{p}\right)$, DEMATEL yönteminin sonucuna göre belirlenmiştir. Toplam etki matrisindeki kısıtlar arasındaki etki dereceleri farklı olduğundan, toplam etki matrisi $T_{p}$ 'nin tüm kısıtları normalleştirilmektedir. Toplam etki matrisi $T_{p}$ 'nin normalleştirilmiş elemanları $t_{i j}^{z}=\frac{t_{i j}^{p}}{\sum^{n}}$ şeklinde olur ve normalleştirilmiş toplam etki

$$
\sum_{i=1}^{n} t_{i j}^{p}
$$

matrisi $T_{Z}$ aşağıdaki gibidir:

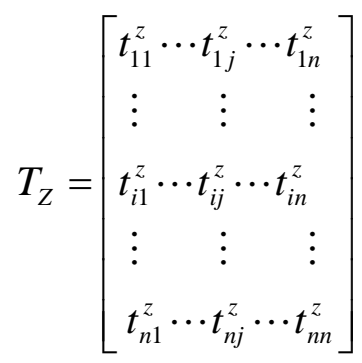

Kullanılan ASS ikili karşıllaştırma ölçeği ise Tablo 5'te verilmiştir. Bu ölçek AHP'de (Analitik Hiyerarşi Prosesi) kullanıldığı gibidir.

Tablo: 5

ASS İkili Karşılaştırma Ölçeği (Saaty, 1980)

\begin{tabular}{|c|c|c|}
\hline Satır-Sütun & Sütun-Satır & Önem Derecesi \\
\hline Sayısal Değeri & Sayısal Değeri & Eşit Derecede Önemli \\
\hline 1 & 1 & Orta Derecede Önemli \\
\hline 3 & $1 / 3$ & Güçlü Derecede Önemli \\
\hline 5 & $1 / 5$ & Çok Daha Güçlü Derecede Önemli \\
\hline 9 & $1 / 7$ & Son Derece Önemli \\
\hline $2,4,6,8$ & $1 / 9$ & Ara Değerler \\
\hline
\end{tabular}

Adım 6: Ağırlıklı Süpermatrisin ( $\left.W_{W}\right)$ Oluşturulması

Ağırlıklı süper matris $\left(W_{W}\right)$, Eşitlik 9 yardımıyla ağırlıksız süper matris $W$ ile normalleştirilmiş toplam etki matrisi $T_{Z}$ çarpılarak hesaplanmaktadır. 


$$
W_{W}=T_{Z} \times W
$$

\section{Adım 7: Limit Süpermatrisin Elde Edilmesi}

Süpermatrisin oluşturulmasından sonra, Eşitlik 10 yardımıyla süpermatris sonsuz defa çarpıldığında ağırlıklar elde edilir. Elde edilmiş süpermatrisin her bir sütunun toplamı 1 'e eşit olacaktır.

$$
\lim _{l \rightarrow \infty} W_{w}^{l}
$$

\section{Uygulama}

Bu çalışmada kayıt dışı istihdama neden olan faktörlerin önem seviyelerinin ve aralarındaki ilişkilerin incelenmesi amaçlanmıştır. Şekil 1'de çalışmada ele alınan bu faktörlerin hiyerarşik yapısı sunulmuştur.

\section{Şekil: 1}

Kayıt Dışı İstihdama Neden Olan Faktörlerin Hiyerarşik Yapısı

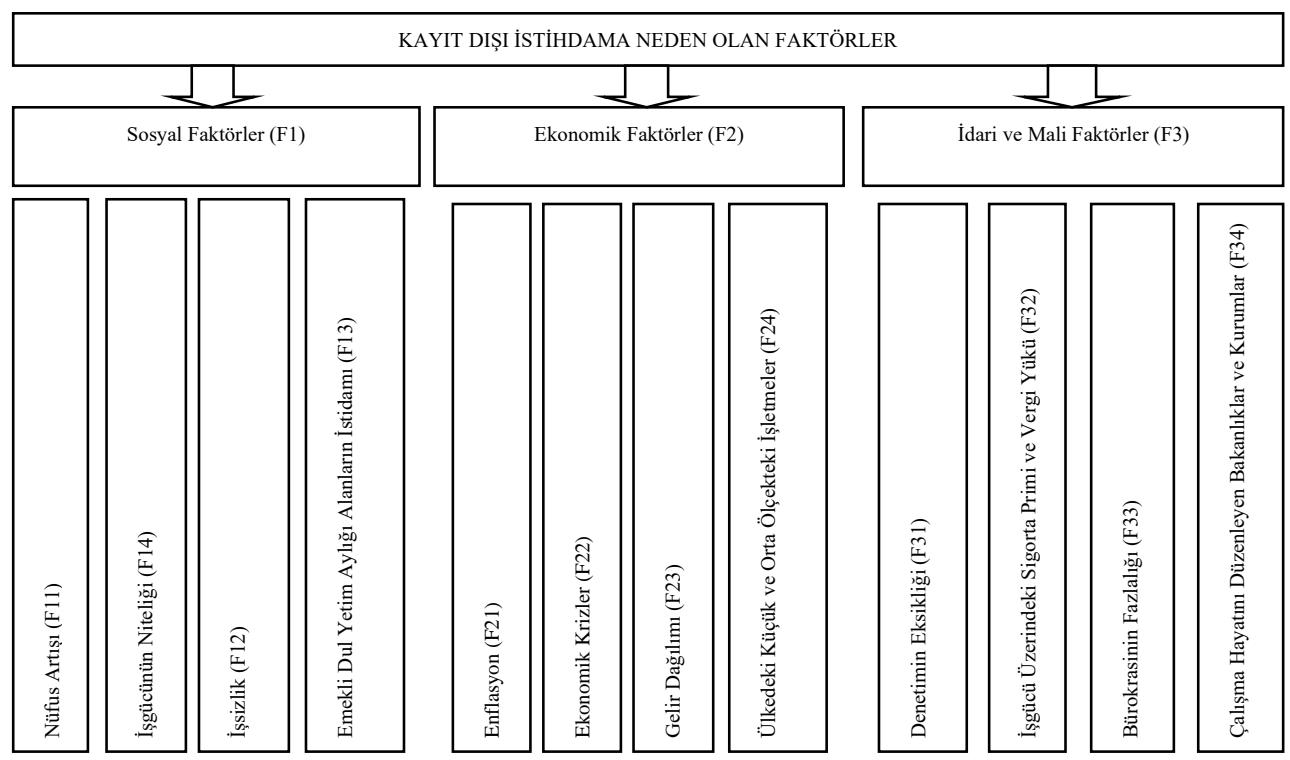

Şekil 1'de ele alınan bu faktörler 3 ana, 12 alt faktörden oluşmaktadır. Araştırmaya katılan uzmanların profilini ise kayıt dışı istihdamla mücadele görevli olan ve alanlarında uzman 5 kişiden oluşmaktadır. Hepsi lisans mezunu ve 10 yıldan fazla süredir SGK'da çalışmaktadır. Eşitlik 1 kullanılarak uzmanların vermiş olduğu cevaplara göre ana faktörler için direkt ilişki matrisi hesaplanarak Tablo 4'te verilmiştir. 
Tablo: 4

Ana Faktörler İçin Direkt İlişki Matrisi

\begin{tabular}{|c|c|c|c|}
\hline Faktörler & F1 & F2 & F3 \\
\hline F1 & 0.0000 & 1,8000 & 1,4000 \\
\hline F2 & 3.0000 & 0.0000 & 2,6000 \\
\hline F3 & 2.0000 & 2.4000 & 0.0000 \\
\hline
\end{tabular}

Eşitlik 2 ve Eşitlik 3 kullanılarak ana faktörler için elde edilen normalize edilmiş direkt ilişki matrisi Tablo 5'te verilmiştir.

Tablo: 5

Ana Kriterler İçin Normalize Edilmiş Direkt İlişki Matrisi

\begin{tabular}{|c|c|c|c|}
\hline Faktörler & F1 & F2 & F3 \\
\hline F1 & 0.8678 & 0.9993 & 0.9309 \\
\hline F2 & 1.6358 & 1.1236 & 1.3949 \\
\hline F3 & 1.3681 & 1.2670 & 0.9303 \\
\hline
\end{tabular}

Eşitlik 4 kullanılarak ana faktörler için elde dilen Toplam ilişki matrisi Tablo 6'da verilmiştir.

Tablo: 6

Ana Faktörler İçin Elde Dilen Toplam İlişki Matrisi

\begin{tabular}{|c|c|c|c|}
\hline Faktörler & F1 & F2 & F3 \\
\hline F1 & 0.0000 & 0.3214 & 0.25 \\
\hline F2 & 0,5357 & 0.0000 & 0,4642 \\
\hline F3 & 0.3571 & 0.4285 & 0.0000 \\
\hline
\end{tabular}

Eşitlik 5, Eşitlik 6 ve Eşitlik 7 kullanılarak oluşturulan ana faktörler arası ilişki diyagramı Şekil 2'de verilmiştir.

Şekil: 2

Ana Faktörler Arası İlişki Diyagramı

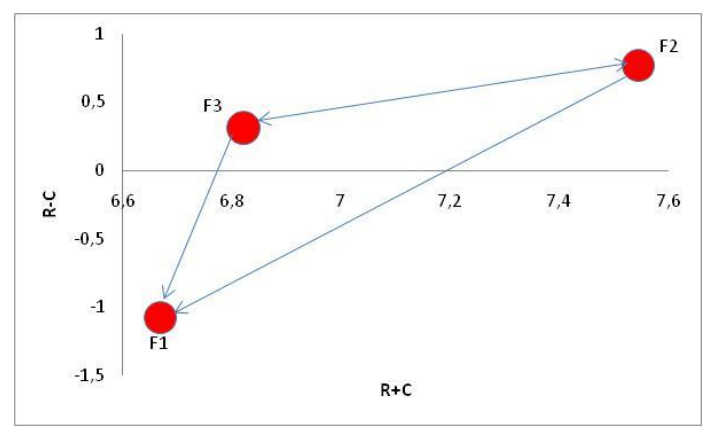

Şekil 2'den de anlaşılacağı gibi Sosyal Faktörler (F1) hem Ekonomik Faktörlerden (F2) hem de İdari ve Mali Faktörlerden (F3) etkilenmektedir. Ayrıca Ekonomik faktörler (F2) ve İdari ve Mali Faktörler (F3) birbirlerini etkilemektedir. Ana faktörlere ait alt faktörlerde yukarıdaki prosedür izlenerek hesaplanmıştır. Tüm etkileyen ve etkilenen faktörler Tablo 7'de sunulmuştur. 
Tablo: 7

Etkileyen ve Etkilenen Faktörler

\begin{tabular}{|c|c|c|c|c|}
\hline Ana Faktörler/Alt Faktörler & $\mathbf{R}$ & $\mathbf{C}$ & $\mathbf{R}+\mathbf{C}$ & R-C \\
\hline Sosyal Faktörler (F1) & 2.798 & 3.872 & 6.670 & -1.074 \\
\hline Nüfus Artışı (F11) & 3.811 & 2.290 & 6.101 & 1.521 \\
\hline İşsizlik (F12) & 3.277 & 3.752 & 7.029 & -0.475 \\
\hline Emekli Dul Yetim Aylığı Alanların İstidamı (F13) & 2.281 & 3.002 & 5.283 & -0.720 \\
\hline İşgücünün Niteliği (F14) & 2.797 & 3.123 & 5.920 & -0.326 \\
\hline Ekonomik Faktörler (F2) & 4.154 & 3.390 & $\mathbf{7 . 5 4 5}$ & 0.764 \\
\hline Enflasyon (F21) & 3.793 & 3.585 & 7.378 & 0.208 \\
\hline Ekonomik Krizler (F22) & 4.299 & 3.227 & 7.525 & 1.072 \\
\hline Gelir Dağılımı (F23) & 3.463 & 3.377 & 6,840 & 0,086 \\
\hline Ülkedeki Küçük ve Orta Ölçekteki İşletme Sayısı (F24) & 2,489 & 3,854 & 6,344 & $-1,366$ \\
\hline İdari ve Mali Faktörler (F3) & 3.566 & 3.256 & 6.822 & 0.309 \\
\hline Denetimin Eksikliği (F31) & 3,146 & 3,320 & 6.467 & -0.174 \\
\hline İşgücü Üzerindeki Sigorta Primi ve Vergi Yükü (F32) & 2.277 & 3.105 & 5.382 & -0.828 \\
\hline Bürokrasinin Fazlalığ 1 (F33) & 2.797 & 2.674 & 5.471 & 0.124 \\
\hline Çalışma Hayatını Düzenleyen Bakanlıklar ve Kurumlar (F34) & 3.748 & 2.870 & 6.619 & 0.878 \\
\hline
\end{tabular}

Tablo 7 incelendiğinde Sosyal Faktörlere (F1) ait alt faktörlerden Nüfus Artış1 (F11) etkileyen; İşsizlik (F12), Emekli Dul Yetim Aylığı Alanların İstidamı (F13) ve İşgücünün Niteliği (F14) ise etkilenen faktörlerdir. Ekonomik Faktörlerden (F2) Enflasyon (F21), Ekonomik Krizler (F22), Gelir Dağılımı (F23) etkileyen; Ülkedeki Küçük ve Orta Ölçekteki İşletme Sayısı (F24) etkilenen faktörlerdir. İdari ve Mali Faktörlerden (F3) Denetimin Eksikliği (F31) ve İşgücü Üzerindeki Sigorta Primi ve Vergi Yükü (F32) etkilenen iken Bürokrasinin Fazlalığı (F33) ve Çalışma Hayatını Düzenleyen Bakanlıklar ve Kurumlar (F34) ise etkileyen faktörlerdendir. Sosyal Faktörlere (F1) ait ilişki diyagramı Şekil 3'te Ekonomik Faktörlere (F2) ait ilişki diyagramı Şekil 4'te ve İdari ve Mali Faktörlere ait ilişki diyagramı Şekil 5'te verilmiştir.

Şekil: 3

Sosyal Faktörlere (F1) Ait İlişki Diyagramı

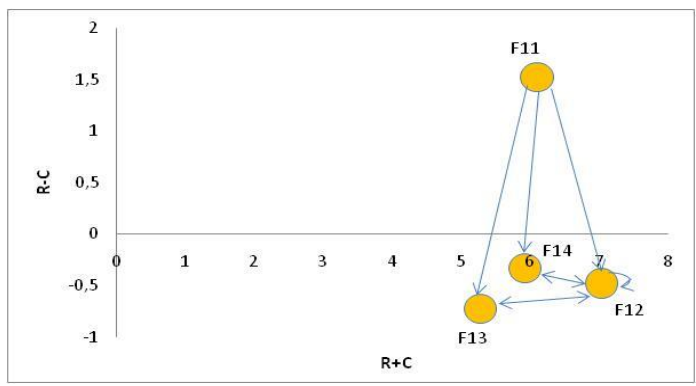


Şekil: 4

Ekonomik Faktörlere (F2) Ait İlişki Diyagramı

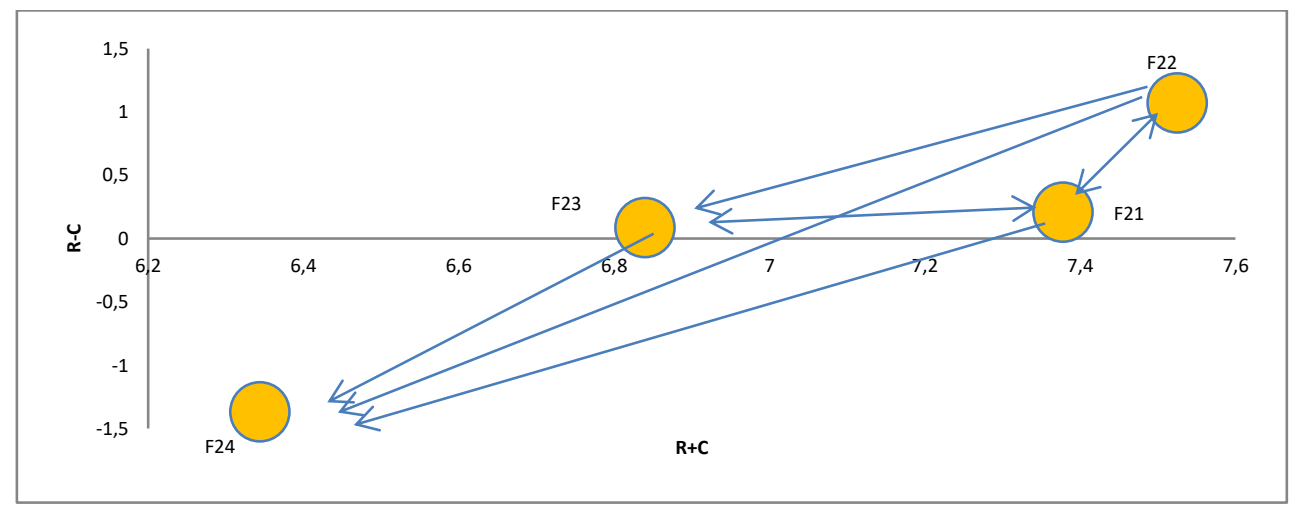

Şekil: 5

İdari ve Mali Faktörlere (F3) Ait İlişsi Diyagramı

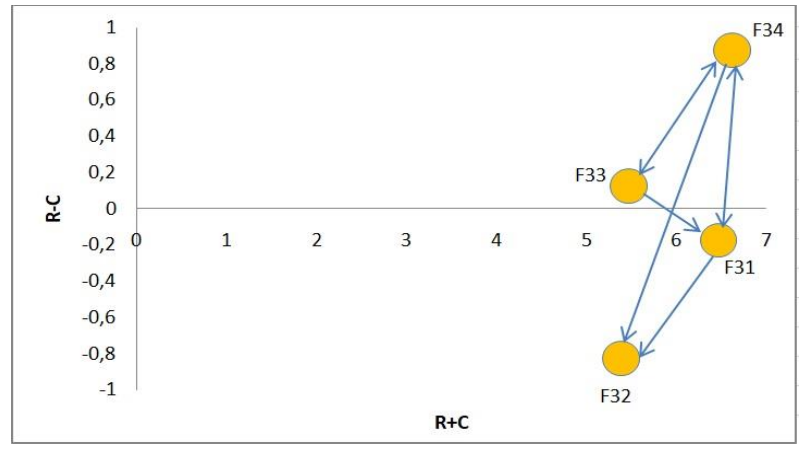

Toplam etki matrisi oluşturulduktan sonra başlangıç süpermatris oluşturulmuştur (Eşitlik 8). Daha sonra başlangıç süpermatrisin ilgili hücreleri ile ana kriterler için oluşturulan başlangıç süpermatrisin ilgili ağılıkları çarpılarak ağırlıklandırılmış süpermatris elde edilmiştir (Eşitlik 9). Ağırlıklandırılmış süpermatrisin ardından limit matris oluşturulmuştur (Eşitlik 10). Aşağıda Tablo 8'de faktörlerin önem dereceleri Şekil 6'da ise alt faktörlerin önem derecelerinin grafiği görülmektedir. 
Tablo: 8

Faktörlerin Önem Dereceleri

\begin{tabular}{|c|c|c|c|c|}
\hline Ana Faktörler & $\begin{array}{l}\text { Ana Faktörlerin } \\
\text { Ağırlıkları }\end{array}$ & Alt Faktörler & $\begin{array}{c}\text { Yerel } \\
\text { Ağırlıklar }\end{array}$ & $\begin{array}{c}\text { Global } \\
\text { Ağırlıklar }\end{array}$ \\
\hline \multirow{4}{*}{ Sosyal Faktörler } & \multirow{4}{*}{0.3275} & Nüfus Artışı & 0.2718 & 0.0890 \\
\hline & & İșsizlik & 0.4044 & 0.1324 \\
\hline & & Emekli Dul Yetim Aylığ Alanların İstidamı & 0.0755 & 0.0247 \\
\hline & & İşgücünün Niteliği & 0.2480 & 0.0812 \\
\hline \multirow{4}{*}{ Ekonomik Faktörler } & \multirow{4}{*}{0.4551} & Enflasyon & 0.2500 & 0.1137 \\
\hline & & Ekonomik Krizler & 0.2648 & 0.1205 \\
\hline & & Gelir Dağılımı & 0.2362 & 0.1074 \\
\hline & & Ülkedeki Küçük ve Orta Ölçekteki İşletme Sayısı & 0.2489 & 0.1132 \\
\hline \multirow{4}{*}{$\begin{array}{l}\text { İdari ve Mali } \\
\text { Faktörler }\end{array}$} & \multirow{4}{*}{0.2172} & Denetimin Eksikliği & 0.2216 & 0.0481 \\
\hline & & İşgücü Üzerindeki Sigorta Primi ve Vergi Yükü & 0.3697 & 0.0802 \\
\hline & & Bürokrasinin Fazlalı̆̆ 1 & 0.2098 & 0.0455 \\
\hline & & $\begin{array}{l}\text { Çalışma Hayatını Düzenleyen Bakanlıklar ve } \\
\text { Kurumlar }\end{array}$ & 0.1987 & 0.0431 \\
\hline
\end{tabular}

Şekil: 6

Alt Faktörlerin Önem Derecelerinin Sıralaması

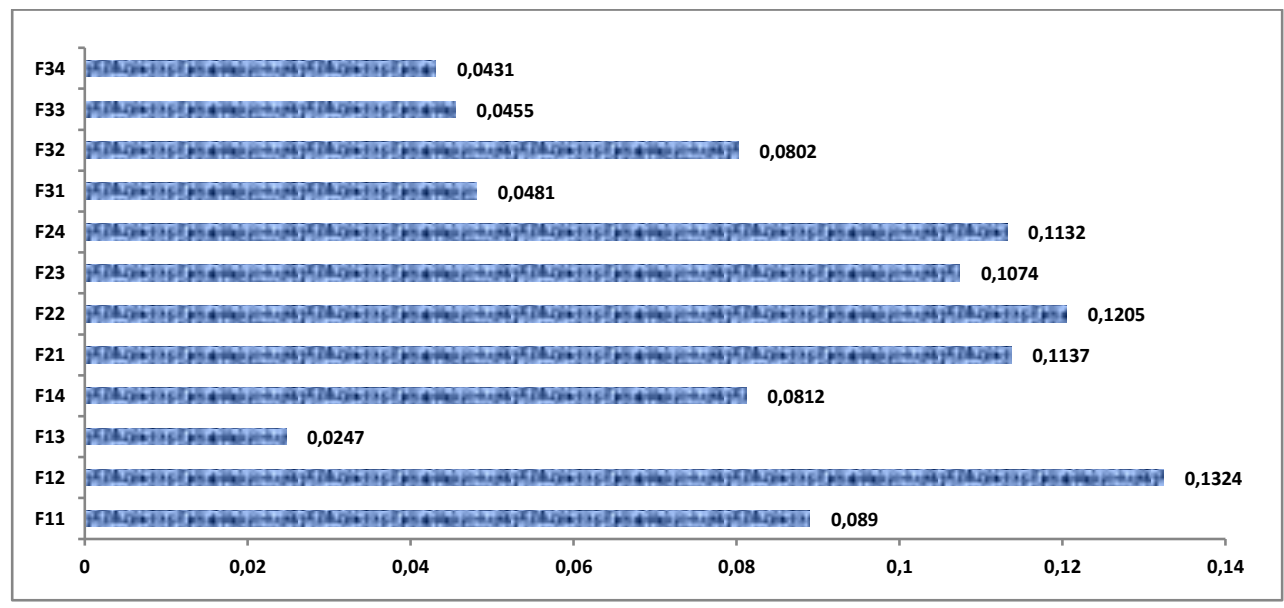

Şekil 6'da görüldüğü üzere ilk üç önemli alt faktör sırasıyla; işsizlik, ekonomik krizler ve enflasyon olarak karşımıza çıkmıştır. Bunun yanında en az önem arz eden faktörler ise; Bürokrasinin Fazlalığı, Çalışma Hayatını Düzenleyen Bakanlıklar ve Kurumlar ve son sırada Emekli, dul ve yetim aylığı olmuştur.

\section{Sonuç}

Her ne kadar kayıt dışı ekonomilerle ilgili faaliyetler sorun teşkil etse de bu durum dünyadaki yaşamın bir gerçekliğidir. Bu sebepten ülkelerin, kaynaklarını daha etkin ve verimli bir şekilde tahsis edebilmeleri için, kayıt dışı unsurları yer üstüne çıkarmaları önem arz etmektedir. Buradaki en önemli husus, kayıt dışıllığı ifade edilmesi ve değişkenleri hakkında bilgi edinilmesi ve ölçülmesinin zorluğudur, çünkü bu faaliyetlerde bulunan bireyler genelde tanımlanmak istemezler. 
Bilindiği üzere gelişmiş ülkelerdeki neo-liberal politikalar işsizliği azaltmadaki başarısızlıkları ve mikro ekonomik verimliliğin sayıcı az fayda yaratması, istihdamın talep boyutunun yönetilmesi yönünde politikaların ihtiyacını ortaya çıkarmaktadır. Yüksek işsizlik sorununun üstesinden gelebilmenin, siyasi iradenin daha kuvvetli olabilmesinden geçtiği vurgulanmaktadır. Türkiye'de ise kayıt dışı istihdam, çalışanları sadece Türk iş kanunu tarafindan korunmaktan mahrum etmekle kalmamakta, aynı zamanda özellikle Sosyal Güvenlik Kurumu açısından bir takım makro-ekonomik etkilerin kaynağı olarak da görülmektedir.

Kayıt dışı istihdam, sadece ekonomik ve toplumsal değil, bütünleşik olarak devletlerin mali kayıplarına da işaret etmektedir. Ülkeler hem dış ticarette dünyada rekabetle baş edebilmek, hem de varlıklarını devam ettirebilmek için başarıda büyük rol oynayan kararlar almaktadırlar. Benzer şekilde daha mikro bir bakış açısı ile şehirler bağlamında, kayıt dışılığın nedenleri irdelenerek her şey kendi özelinde gerekli politikalar geliştirilebilir. Ülkemizin kayıt dışı istihdam ile mücadelesi doğrultusunda en etkin neden/nedenlerin belirlenmesinin amaçlandığı kayıt dışı istihdam nedenleri, nitel ve nicel olarak çok sayıda faktörü bünyesinde barındıran çok kriterli karar verme problemi olarak adlandırılabilir.

Kayıt dışı istihdamı etkileyen faktörlerin önem dereceleri, değerlendiricilerin uzmanlıklarına (ülkelerin gelişmişlik düzeyi, genel konjonktür, uzmanlık alanlarının farklılığ 1 vd. durumlara göre kriterler değişebilir) bağlı olarak değişken bir yapıdadır. Kabul edilebilir, gerçekçi ve uygulanabilir bir kayıt dışı istihdam nedenlerinin seçimi ve analizi adına uzman görüşleri dikkate alınarak faktör ağırlıkları DEMATEL ve ANP yöntemlerinden yararlanılarak hesaplanmıştır. Faktörlerin ağırlık değerleri incelendiğinde kayıt dışı istihdama sebep olan nedenler için önem derecesi en büyük olan faktörler sırasıyla ekonomik nedenler, sosyal nedenler ve idari ve mali nedenlerdir. Ekonomik nedenlerin öncülüğü çektiği bulgusu, alt faktörler bakımından incelendiğinde ise; işsizlik, ekonomik krizler ve enflasyon ilk üç önem sıralamasıyla sonuçlar arasında yer almıştır. Karşılıklı etki durumlarına bakıldığında ise, sosyal faktörlerin; ekonomik ve mali faktörlerden etkilendiği sonucuna ulaşılmıştır. Kayıt dışı istihdam problemini çok kriterli bir karar verme modeliyle çözümleyen bu araştırma, bu yönü ile literatürde yöntemi ile katkı sağlayacaktır.

Bu sonuçlar göz önüne alındığgnda, her hükümet için en büyük zorluklardan birinin, kayıt dışı olan durumu daha az çekici hale getirmek ve böylece kayıtlı ekonomide çalışmak için etkili teşvik odaklı politika önlemleri almak olduğu açıktır. Bu tür politikaların başarılı bir şekilde uygulanması, kayıt dışı boyutunun istikrarlı devam etmesine, hatta azalmasına yol açabilir. Ancak literatürdeki son 20 yıllık yoğun araştırmalardan sonra bile, büyüklüğü, nedenleri ve sonuçları hakkındaki anlayışı geliştirmek için daha fazla araştırmanın gerekli olduğunu gösteren bir durum olduğu aşikardır. Politika yapıcılar açısından ilgili sonuçlar ve bu çalışmanın katkısı değerlendirilmesi gereken bir bilgi niteliğindedir.

\section{Kaynaklar}

Aydemir, Ş. (1994), Türkiye'de Kayıt Dışı Ekonomi, Acar Matbaası, İstanbul.

Casson, M. \& M.G. Della \& U. Kambhampati (2010), "Formal and informal institutions and development", World Development, 38(2),137-141. 
Chong, A. \& M. Gradstein (2007), "Inequality and informality”, Journal of PublicEconomics, 91(12), 159-179.

Dam, M.M. \& Ş. Ertekin \& N. Kızılca (2018), “Türkiye'de Kayıt Dış1 İstihdamın Boyutu: Ekonometrik Bir Analiz”, Dokuz Eylül Üniversitesi İktisadi İdari Bilimler Fakültesi Dergisi, 33(1), 293-318.

Dreher, A. \& F. Schneider (2010), "Corruption and the Shadow Economy: An Empirical Analysis", Public Choice, 144 (1), 215-238.

Feld, L.P. \& F. Schneider (2010), "Survey on the shadow economy and undeclared earnings in OECD countries", German Economic Review, 11(2), 109-149.

Fialová, K. \& O. Schneider (2011), "Labor institutions and their impact on shadow economies in Europe", World Bank Policy Research Working Paper, (5913).

Fidan, H. \& S. Genç (2013), "Kayıtdışı İstihdam ve Kayıtdışı İstihdama Etki Eden Mikro Faktörlerin Analizi: Türkiye Özel Sektör Örneği”, Mehmet Akif Ersoy Üniversitesi Sosyal Bilimler Enstitüsü Dergisi, 5(9), 137-150.

Fontela, E. \& A. Gabus (1976), "The DEMATEL Observer”, DEMATEL 1976 Report, Battelle Geneva Research Center, Switzerland, Geneva.

Frey, B.S. \& H. Weck (1983), "Bureaucracy and the Shadow Economy: A Macro-Approach", içinde: H. Hanusch (ed.), Anatomy of Government Deficiencies, Berlin: Springer, 89-109.

Galiani, S. \& F. Weinschelbaum (2012), "Modeling informality formally: house holds and firms", Economic Inquiry, 50(3), 821-838.

Harker, P.T. \& L.G. Vargas (1987), “The theory of ratio scale estimation: Saaty's analytic hierarchy process", Management Science, 33(11), 1383-1403.

Hazans, M. (2011), "Informal workers across Europe: Evidence from 30 European countries", World Bank Policy Research Working Paper, (5912).

Heritage Foundation (2011), The 2011 Index of Economic Freedom, <http://www.heritage.org/index>, 14.02.2021.

Hwang, B.-N. \& N.-Y. Pai \& C.-C. Lu \& Y. Keny (2014), "The Design Decision of Online Game Development Based on a MCDM Model Combining Dematel with ANP Method", Journal of Theoretical \& Applied Information Technology, 63(2), 486-498.

Johnson, S. \& D. Kaufmann \& A. Shleifer \& M.I. Goldman \& M.L. Weitzman (1997), "The unofficial economy in transition", Brookings papers on economic activity, 1997(2), 159239.

Johnson, S. \& D. Kaufmann \& P. Zoido-Lobatón (1998), "Regulatory Discretion and the Unofficial Economy", The American Economic Review, 88(2), 387-392.

Jonasson, E. (2012), “Government effectiveness and regional variation in informal employment", Journal of Development Studies, 48(4), 481-497.

Korkmaz, A. (2003), “Türkiye'de Kayıtdışı İstihdam Gerçeğine Bir Bakış”, Sosyal Siyaset Konferanslarl Dergisi, (45), 51-96.

Langbein, L. \& S. Knack (2010), “The world wide governance indicators: six, one, ornone?”, Journal of Development Studies, 46(2), 350-370.

Mahiroğulları, A. (2017), “Türkiye'de Kayıtdışı İstihdam ve Önlemeye Yönelik Stratejiler”, Suleyman Demirel University Journal of Faculty of Economics \& Administrative Sciences, 22(2), 547-565. 
Muhammad, M.N. \& N. Cavus (2017), "Fuzzy DEMATEL Method for Identifying LMS Evaluation Criteria", Procedia Computer Science, 120, 742-749.

OECD/ILO (2019), Tackling Vulnerability in the Informal Economy, Development Centre Studies, OECD Publishing, Paris.

Perry, G.E. \& O. Arias \& P. Fajnzylber \& W.F. Maloney \& A. Mason \& J. Saavedra-Chanduvi (2007), Informality: Exit and exclusion, The World Bank.

S.S.K. (2000), 2000 Yılı İstatistik Yılliğl.

S.S.K. (2001), 2001 Yllı İstatistik Yıllı̆̆l.

Schneider, F. \& A. Buehn \& C.E. Montenegro (2010), "Shadow economies all over the world: New estimates for 162 countries from 1999 to 2007”, World Bank policy research working paper, (5356).

Schneider, F. \& D. Enste (2000), “Shadow Economies: Size, Causes, and Consequences”, The Journal of Economic Literature, 38(1): 77-114.

Shieh, J.-I. \& H.-H. Wu \&K.-K. Huang (2010), “A DEMATEL Method in Identifying Key Success Factors of Hospital Service Quality”, Knowledge-Based Systems, 23(3), 277-282.

Taylor, M.P. (1996), "Earnings, Independence or Unemployment: Why Become Self Employed?" Oxford Bulletin of Economics and Statistics, 58(2), 253-265.

Toptaş, Ü. (1998), “Türkiye'de Kayıtdışı Ekonominin Nedenleri”, Türkiye Esnaf-Sanatkâr ve Küçük Sanayi Araştırma Enstitüsü (TES-AR) Yayınlarl, Ankara.

Us, V. (2004), “Kayıt Dışı Ekonomi Tahmini Yöntem Önerisi: Türkiye Örneği”, Discussion Paper, No. 2004/17, Turkish Economic Association, Ankara.

Watts, M.J. (2000), “The Dimensions and Costs of Unemployment in Australia”, içinde: S. Bell (ed.) The Unemployment Crisis: Which Way Out?, Cambridge University Press, 21-48.

Wu, W.-W. (2008), "Choosing Knowledge Management Strategies by Using a Combined ANP and DEMATEL Approach”, Expert Systems with Applications, 35(3), 828-835. 